\title{
Penerapan Qanun Aceh Nomor 14 Tahun 2003 Tentang Khalwat (Mesum) \\ (Studi Kasus Penerapan Syariat Islam di Kota Subulussalam)
}

\author{
Ali Geno Berutu \\ Sekolah Pascasarjana (SPs) \\ UIN Syarif Hidayatullah Jakarta \\ ali_geno@ymail.com
}

\begin{abstract}
This paper discusses the implementation of Aceh's Qanun (the regional law) Number 14 of 2003 on khalwat (mesum/adultery) in Subulussalam city. The current study aims to explain the strategies to deal with the cases of khlawat in Aceh. It was field and library research by carrying out qualitative method and socio-legal-historic approach. The research findings reveal that the cases of khlawat could be solved through the pivotal roles of the local customary court (Mahkamah Adat) and Islamic court (Mahkamah Syar'iyah). The roles arose an uncertainty in handling the cases, particularly for the law enforcement agencies (WH, police officers, prosecutors, and the Mahkamah Syar'iyah). Additionally, the Acehnese Qanun Number 9 of 2008 on the preservation of customary law has explicitly established the problem-solving of lawsuit and its mechanism in an exclusive chapter. The Article 13 Section 1 in this Qanun asserts that the types of lawsuit/dispute of local customs consist of 18 issues. Khalwat is one of the involved issues, and the Mahkamah Adat is the authorized party concerning the issue.
\end{abstract}

Keywords: Aceh, Islamic Law, Khalwat, Jinayat. 


\section{Abstrak}

Artikel ini mengkaji penerapan qanun Aceh nomor 14 Tahun 2003 tentang khalwat (mesum) di kota Subulussalam. Tujuan penelitian ini adalah untuk menjelaskan strategi penanganan kasus khalwat di Aceh. Penelitian ini adalah penelitian lapangan (field research) dan penelitian kepustakaan (library research) dengan metode kualitatif dan menggunakan pendekatan sosio-legal-historis. Dimana kasus khalwat di Aceh dapat diselesaikan melalui mahkamah adat dan mahkamah syar'iyah, dengan demikian timbul suatu ketidakpastian dalam penanganan kasus tersebut khususnya bagi lembaga penegah hukum (WH, Polisi, Jaksa dan Mahkamah Syar'iyah). Bila kita amati dalam Qanun Aceh No. 9 Tahun 2008 tentang Pembinaan Kehidupan dan Adat Istiadat telah di atur secara tegas dalam bab tersendiri mengenai penyelesaian sengketa dan mekanismenya. Pasal 13 ayat (1) menegaskan bahwa jenis sengketa/perselisihan adat dan adat istiadat meliputi 18 perkara dan khalwat (mesum) merupakan salah satu perkara yang menjadi kewenangan mahkamah adat di Aceh.

Kata Kunci: Aceh, Syariat Islam, Khalwat, Jinayat.

\section{Pendahuluan}

Khalwat (mesum) adalah perbuatan yang dilakukan oleh dua orang yang berlawanan jenis atau lebih tanpa ikatan nikah (bukan muhrim) pada tempat tertentu yang sepi dan memungkinkan terjadinya perbuatan maksiat di bidang seksual atau yang berpeluang pada tejadinya perbuatan perzinaan. Islam dengan tegas melarang melakukan zina, sementara khalwat ditenggarai menjadi wasilah untuk terjadinya zina (Hifdhotul Munawaroh, 2013:154) Qanun Aceh dalam upaya preventif dan tercapainya penerapan syariat Islam di Aceh secara kaffah telah memasukkan khalwat ke dalam kategori jarimah (perbuatan pidana) dan dapat diancam dengan 'uqubatta'zir. 
Dalam perkembangannya khalwat tidak hanya terjadi di tempat-tempat tertentu yang sepi dari penglihatan orang lain, tetapi juga dapat terjadi di tengah keramaian atau di jalanan dan di tempattempat lain seperti dalam mobil atau kenderaan lainnya, dimana lakilaki dan perempuan berasyik maksyuk tanpa ikatan nikah atau hubungan mahram (Qanun Nomor 14 Tahun 2003). Qanun tentang larangan khalwat ini dimaksudkan sebagai upaya preemtif, preventif dan pada tingkat optimum remedium sebagai usaha represif melalui penjatuhan 'uqubat dalam bentuk 'uqubat ta'zi» yang dapat berupa 'uqubatcambuk dan 'uqubatdenda (gdramah).

Qanun Khalwat (mesum) bila dilihat dari jenis perbuatan melawan hukumnya bukan suatu hal yang baru, hal yang sama ditemui dalam aturan kesusilaan yang ada dalam Kitab Undangundang Hukum Pidana (KUHP). Terlepas dari kontroversi yang dimilikinya, KUHP produk kolonial ini jauh-jauh hari telah mengatur soal kesusilaan, bahkan jauh lebih rinci dibanding Qanun Khalwat. Dalam qanun tersebut khalwat didefinisikan sebagai perbuatan bersunyi-sunyi antara dua orang mukallaf atau lebih yang berlainan jenis yang bukan muhrim atau tanpa ikatan perkawinan. Sementara dalam KUHP hal-hal "kecil" yang merupakan perbuatan asusila bahkan mendapat hukuman, pandangan seperti ini dikemukakan oleh Muhammad Yani dalam tesisnya yang berjudul Pelaksanaan Hukum Jinayat di Aceh Perspektif Fik\}ih dan HAM yang di kutip dari Komnas Perempuan (Muhammad Yani, 2011).

Namun demikian keduanya tetap memiliki perbedaan orientasi hukum, perbuatan khalwat akan tetap ditindak baik dilakukan di tempat umum (terbuka) maupun di tempat tertutup, artinya orientasi hukum pengaturan khalwat adalah untuk kemaslahatan dan kemanfaatan pribadi seseorang dan juga orang lain. Manfaat pribadi agar seseorang tidak melakukan perbuatan yang mengarah pada perbuatan zina yang dilarang oleh agama dan mengakibatkan dosa dan siksa di kemudian hari. Sementara manfaat bagi orang lain adalah melindungi masyarakat dari berbagai bentuk kegiatan dan atau perbuatan yang merusak kehormatan. 
Sebagaimana dikemukakan dalam Pasal 3 Qanun No. 14 Tentang Khalwat dimana tujuan larangan khlawat adalah untuk melindungi masyarakat sedini mungkin dari melakukan perbuatan yang mengarah kepada zina dan merusak kehormatan dan melindungi masyarakat dari berbagai bentuk kegiatan dan/atau perbuatan yang merusak kehormatan.

Dalam KUHP perbuatan asusila akan ditindak sebagai pelanggaran hukum ketika dilakukan di muka umum, sementara jika dilakukan ditempat tertutup tidak lagi menjadi obyek hukum. Orientasi hukum pidana tentang pengaturan kesusilaan ini mengarah pada upaya melindungi orang lain untuk tidak terganggu atau terpengaruh oleh tindakan yang menyebabkan timbulnya birahi orang lain. Perbandingan antara Qanun Khalwat dan KUHP itu menunjukkan bahwa secara materil pengaturan khalwat tidak memiliki justifikasi dari produk perundang-undangan di atasnya, bahkan dalam konsideran qanun tersebut tidak disebutkan KUHP sebagaimana ulasan di atas padahal KUHP juga mengatur hal serupa. Konsideran utama yang disebutkan qanun itu adalah Alquran dan Sunnah serta Qanun No. 5 Tahun 2000 tentang Pelaksanaan Syariat Islam, karena itu secara materil qanun ini hanya memiliki justifikasi syariat Islam semata meskipun ia tetap tidak bisa dipersoalkan (uji materil) karena berdasarkan UU No. 44 Tahun 1999 dan UU No. 18 Tahun 2001 Aceh ditetapkan sebagai daerah yang diperintahkan oleh hukum untuk menjalankan syariat Islam (Komnas Perempuan, 2015).

Jika Qanun Khamar dan Maisir dianggap tidak mengalami kontradiksi dengan perundang-undangan lainnya, maka Qanun Khalwat mengalami kontradiksi dengan perundang-undangan lainnya. Pembatasan jenis tindak pidana khalwat yang sangat luas berimplikasi pada penafsiran hukum yang sangat liar, pengaturan khalwat ini jika dihadapkan pada UU tentang Hak Asasi Manusia, UU Ratifikasi CEDAW jelas-jelas mengalami kontradiksi yang signifikan (Husnul Arifin Melayu, 2011: 74).

Jika di satu sisi kehadiran Qanun Khlawat dianggap memiliki justifikasi politik karena ia merupakan manifestasi dari pendelegasian 
kewenangan dalam penyusunan peraturan daerah, sebagaimana diatur dalam UU No. 18 Tahun 2001 Tentang OTSUS bagi Aceh, maka di sisi lain ruang untuk mempersoalkan kontradiksi yang diidap dalam qanun ini juga dibenarkan oleh UU yang sama. UU OTSUS memang tidak membatasi secara tegas kewenangan penyusunan peraturan daerah oleh otoritas Aceh, misalnya dengan memagari bahwa setiap produk peraturan daerah tidak boleh bertentangan dengan UU HAM, UU Ratifikasi CEDAW dan lain sebagainya. Tapi sebagaimana ditetapkan dalam Ketentuan Peralihan dalam Pasal 29 UU OTSUS dijelaskan bahwa "semua peraturan perundang-undangan yang ada sepanjang tidak diatur dengan undang-undang ini dinyatakan tetap berlaku di Aceh". Hal ini menunjukkan bahwa masih banyak produk hukum nasional yang dapat dijadikan alat penilai bagi qanun yang disusun oleh otoritas Aceh. Jika mengacu pada argumen ini, maka kontradiksi yang diidap oleh qanun khalwat ini semakin terbuka untuk dipersoalkan. Dari uraian di atas terlihat bahwa salah satu akar masalah kontradiksi ini juga diidap oleh UU OTSUS itu sendiri yang tidak holistik mengatur soal-soal kewenangan otoritas Pemerintahan Aceh. Oleh karena itu, artikel ini bertujuan untuk: pertama, menjelaskan pengaturan pelaksanaan tindak pidana pelanggaran Qanun No. 14 Tahun 2003 di Kota Subulussalam. Kedua, menjelaskan langkah-langkah yang ditempuh oleh pemerintah dalam mensosialisasikan, memberikan pemahaman dan pengetahuan tentang Qanun Jinayat kepada masyarakat Kota Subulussalam. Ketiga, menjelaskan faktor yang mempengaruhi penegakan Qanun Khalwat Di Kota Subulussalam.

\section{Metodologi}

Penelitian ini bersumber dari penelitian lapangan (field research) dan penelitian kepustakaan (library research) dengan metode kualitatif dan menggunakan pendekatan sosio-legal-historis. Pendekatan sosiologis digunakan untuk mengamati dan mengetahui bagaimana peran hukum terhadap perilaku sosial ditengah masyarakat, pendekatan yuridis/legal digunakan untuk melihat hukum sebagai law in action, 
dideskripsikan sebagai gejala sosial yang empiris. Dengan demikian, hukum tidak sekedar diberikan arti sebagai jalinan nilai-nilai, keputusan pejabat, jalinan kaidah dan norma, hukum positif tertulis, tetapi juga dapat diberikan makna sebagai sistem ajaran tentang kenyataan, perilaku yang teratur dan ajeg atau hukum dalam arti petugas. Penelitian hukum empiris ini tidak hanya tertujuan pada warga-warga masyarakat, akan tetapi juga pada penegak hukum dan fasilitas yang diharapkan menunjang pelaksanaan peraturan tersebut (Sorjono Soekanto, 2005:32). Pendekatan historis digunakan sebagai perbandingan terhadap pemberlakuan Qanun Aceh di Kota Subulussalam, sebelum dan sesudah pemberlakuan UU No. 44 tahun 1999 sebagai dasar penerapan syariat Islam di Aceh.

\section{Hasil Penelitian dan Pembahasan}

3.1. Ketentuan Uquba Terhadap Pelanggar Qanun No. 14 Tahun 2003

Mengenai 'uquba terhadap pelanggar qanun ini dijelaskan dalam BAB VII Pasal 22 ayat 1-2 disebutkan bahwa setiap orang yang melanggar ketentuan sebagaimana dimaksud dalam Pasal 4 diancam dengan 'uqubat $t a$ ' $z$ i $>$ berupa cambuk paling banyak 9 (sembilan) kali dan paling rendah 3 (tiga) kali dan/atau dendan paling banyak Rp. 10.000.000,- (sepuluh juta rupiah) dan paling sedikt Rp. 2.500.000,(dua juta lima ratus ribu rupiah); Setiap orang yang melanggar ketentuan sebagaimana yang dimaksud dalam Pasal 5 diancam dengan 'uqubat $t a$ 'zi berupa kurungan paling lama 6 (enam) bulan dan paling singkat 2 (dua) bulan dan/atau denda paling banyak Rp. 15.000.000,- (lima belas juta rupiah) dan paling sedikit Rp. 5000.000,(lima juta rupiah).

Pelanggaran terhadap ketentuan sebagaimana dimaksud dalam Pasal 5 dan Pasal 6 apabila dilakukan oleh badan hukum/badan usaha maka 'uqubatnya dijatuhkan kepada penanggung jawab. Jika ada hubungan dengan kegiatan usahanya maka selain 'uqubat sebagaimana dimaksud dalam Pasal 22 ayat (1) dan (2) dapat juga dikenakan 'uqubat administratif. Sedangkan 
pengulangan pelanggaran (residivist) terhadap ketentuan sebagaimana dimaksud dalam Pasal 22 'uqubatnya dapat ditambah 1/3 (sepertiga) dari 'uqubat maksimal. Dalam Qanun No. 14 Tahun 2003 menjelaskan bahwa hukum khalwat adalah haram dan melarang kepada setiap orang untuk melakukan khalwat, larangan yang sama juga ditujukan kepada orang atau kelompok masyarakat atau aparatur pemerintah atau badan usaha dilarang untuk memberikan fasilitas kemudahan atau melindungi orang yang berbuat khalwat.

\subsection{Penegakan Qanun No. 14 Tahun 2003 Di Kota Subulussalam}

Penyelesaian kasus khalwat di Kota Subulussalam kebanyakan dilakukan menggunakan sistem kekeluargaan atau menyelesaikan kasus menggunakan adat setempat, dengan cara melakukan perdamaian maupun diberikan nasehat dan teguran oleh para petua atau bahkan dinikahkan untuk menghindari fitnah atau aib bagi keluarga (H.M Layari Kombih, 2015). Tercatat sampai pada tahun 2015 baru satu kasus khalwat yang diselesaikan melalui proses peradilan yang berujung kepada penjatuhan sanksi cambuk kepada pelaku tersebut.

\section{Tabel 1}

Pelanggaran Qanun Khalwat di Kota Subulussalam 3 Tahun Terakhir

\begin{tabular}{|c|c|c|c|}
\hline \multirow[b]{2}{*}{ Tahun } & \multirow{2}{*}{$\begin{array}{c}\text { Jumlah } \\
\text { Kasus }\end{array}$} & \multicolumn{2}{|c|}{ Penyelesaian } \\
\hline & & $\begin{array}{c}\text { Adat/Teguran/ } \\
\text { Pembinaan }\end{array}$ & Mahkamah Syar'iyah \\
\hline 2013 & 2 & $\checkmark$ & - \\
\hline 2014 & 12 & $\checkmark$ & - \\
\hline 2015 & 2 & $\checkmark$ & $\checkmark$ \\
\hline
\end{tabular}

* Sumber: Kompilasi Jurnlah Kasus Kantor Pol PP danWilayatul Hisbah Kota Subulussalam

Pada bagian ini penulis mengklasifikasikan penyelesaian kasus khalwat di Kota Subulussalam kepada dua bentuk penyelesaian, 
pertama penyelesaian dengan jalur adat, teguran dan pembinaan. Kedua penyelesain melaui pengadilan di mahkamah syari'yah.

\subsection{Penyelesaian Melaui Adat, Teguran dan Pembinaan}

Penyelesaian khalwat (mesum) di Kota Subulussalam sebagaimana yang dijelaskan Kasi Penegak Kebijakan Daearah Dan Syariat Islam Kota Subulussalam bahwa, setiap pelanggaran kasus khalwat di wilayah hukum Kota Subulussalam terlebih dahulu dilakukan penyelesaian dengan cara kekeluargaan dan adat istiadat yang berlaku di Subulussalam. Setelah pihak Satpol PP dan WH memberikan teguran dan peringatan kepada para pihak yang melanggar qanun tentang khalwat tersebut, lalu menyerahkannya kepada geucik (kepala desa) untuk diselesaikan secara adat dan aturan kampung tersebut, setelah dilakukan proses hukum adat tapi belum menghasilkan suatu kesepakatan, baru diselesaikan secara qanun yang berlaku (Kalidin, 2015).

\section{Tabel 2}

\section{Skema Penyelesaian Kasus Khalwat} Melalui Peradilan Adat
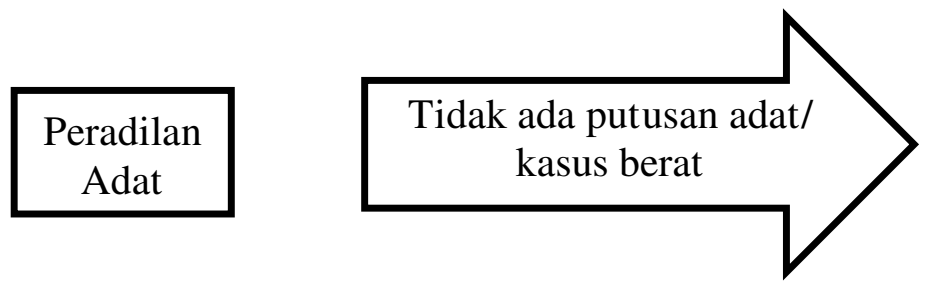

Mahkamah Syar'iyah

Kewenangan lembaga adat dalam penyelesaian kasus khalwat (mesum) di Kota Subulussalam yaitu untuk mendamaikan perkara dengan rapat adat gampong (desa), yang dipimpin oleh geuchik (kepala desa), apabila dalam jangka waktu dua bulan kasus tersebut tidak dapat diselesaikan, maka kasus itu dapat diteruskan ke tingkat kemukiman yang dipimpin oleh Imeum Mukim atau nama lain, adalah kesatuan masyarakat hukum dalam Provinsi Nanggroe Aceh Darussalam yang terdiri atas gabungan beberapa Gampong yang mempunyai batas wilayah tertentu dan harta kekayaan sendiri, berkedudukan langsung di bawah Camat atau nama lain yang 
dipimpin oleh imeum mukim atau nama lain. Lihat Pasal 1 ayat (4) Qanun No. 4 Tahun 2003 Tentang Pemerintahan Mukim, bila Imeum Mukim dalam jangka waktu satu bulan tidak dapat menyelesaikannya, kasus tersebut baru dapat diteruskan kepada aparat hukum yaitu wilayatul hisbah (H.M Layari Kombih, 2015)

Majelis Adat Aceh (MAA) Kota Subulussalam juga membenarkan hal tersebut, menurutnya semua kasus yang menjadi lingkup peradilan adat di Kota Subulussalam harus terlebih dahulu diupayakan penyelesaiannya melalui jalur adat, setelah diupayakan melalui jalur adat dan tidak ditemukan satu titik temu (penyelsaian) baru diserahkan kepada para penegak hukum WH dan Kepolisian (H.M Layari Kombih, April 2015). Penyelesaian perkara jinayatmelaui WH dan MS yang natinya berujung kepada penjatuhan hukuman cambuk bukanlah menjadi suatu kebanggaan bagi Kota Subulussalam (M Ya'qub KS, 2015). MAA Kota Subulussalam yang menyebutkan bahwa penghukuman tidak hanya melihat pada soal membuat orang sejera-jeranya, tetapi ada aspek lain yang harus dilihat yaitu pembelajaran. Bagaimana menjamin orang tidak mengulangi perbuatan tersebut, ini jauh lebih penting dalam aspek penegakan hukum (Restorative Justice) (Kuat Puji Prayitno, 2012: 409-411) yang mengandung prinsip dasar meliputi:

a. Mengupayakan perdamaian di luar pengadilan oleh pelaku tindak pidana (keluarganya) terhadap korban tindak pidana (keluarganya);

b. Memberikan kesempatan kepada pelaku tindak pidana (keluarganya) untuk bertanggung jawab menebus kesalahannya dengan cara mengganti kerugian akibat tindak pidana yang dilakukannya;

c. Menyelesaikan permasalahan hukum pidana yang terjadi diantara pelaku tindak pidana dan korban tindak pidana tersebut apabila tercapai persetujuan dan kesepakatan diantara para pihak.

Sehingga dapat diartikan bahwa restorative justice adalah suatu rangkaian proses penyelesaian masalah pidana di luar pengadilan 
yang bertujuan untuk me-restore (memulihkan kembali) hubungan para pihak dan kerugian yang diderita oleh korban kejahatan dan diharapkan dapat dijadikan dasar pertimbangan bagi majelis hakim pengadilan pidana dalam memperingan sanksi pidana yang dijatuhkan terhadap pelaku tindak pidana tersebut. Restorative Justice dalam ilmu hukum pidana harus bertujuan untuk memulihkan kembali keadaan seperti sebelum terjadi kejahatan.

Berikut adalah beberapa contoh kasus khalwat di Kota Subulussalam yang diselesaikan dengan adat dan kekeluargaan: Contoh pertama, A (23) warga Aceh Selatan pelanggar laki-laki dengan R (30) warga Subulussalam pelanggar perempuan yang melakukan pelanggaran Qanun Aceh Nomor 14 Tahun 2003 tentang Khalwat (mesum) yang telah dilakukan pada hari Minggu 24 Nopember 2013 pukul 23:00 WIB, dengan tempat kejadian di komplek terminal Kota Subulussalam. Sepasang muda-mudi tersebut terjaring dalam razia rutin bulanan yang dilakukan oleh Pol PP dan WH Kota Subulussalam. Contoh kedua, Satuan Polisi Pamong Praja (Pol PP) dan Wilayatul Hisbah (WH) Kota Subulussalam menangkap sepasang muda-mudi yang diduga telah melakukan pelanggaran khalwat (mesum), pelakunya adalah AY (22) warga Abdia dengan seorang peremuan PZ (20) warga Aceh Besar, pada hari Senin Tanggal 10 Juni 2013 pada Pukul 01:00 WIB bertempat di penginapan Jambu Alas Kec. Penanggalan Kota Subulussalam. Setelah diberi teguran dan pembinaan oleh petugas SatPol PP dan WH Kota Subulussalam karena melanggar Qanun Nomor 14 Tahun 2003 tentang Khalwat (mesum), pelaku pelanggar khalwat berjanji tidak akan mengulangi pelanggaran kembali dan bersedia dihukum sesuai ketentuan yang berlaku di Kota Subulussalam (Data Berdasarkan Jurnal Kasus,Satuan Polis Pamong Peraja Dan Wilayatul Hisbah Kota Subulussalam Tahun 2013). Contoh ketiga, Petugas WH dan Pol PP Kota Subulussalam melakukan razia rutin bulanan keberapa lokasi yang di indikasikan menjadi tempat pelanggaran qanun jinayat, razia ini dilakukan pada tanggal 8 September 2012. Gabungan WH dan Pol PP melakukan razia di beberapa tempat, salah satunya adalah Kafe Hikmah yang berada di Gampong Lae Mbersih Kecamatan Penanggalan, dari lokasi 
ini petugas gabungan Pol PP dan WH berhasil mengamankan tiga pasang remaja yang sedang berduaan di kafe remang-remang tersebut, padahal waktu kejadian tersebut sudah menunjukkan pukul 23.15 WIB, di lokasi petugas juga menemukan alat kontrasepsi bekas pakai. Petugas WH hanya memberikan teguran kepada pemilik kafe untuk tidak lagi menyediakan fasilitas warung remang-remang, pasangan remaja di sana juga dinasehati serta membuat surat pernyataan tidak mengulangi perbuatannya, karena jika kedapatan melakukan perbuatan serupa, akan dikenakan sanksi sesuai qanun (http:// www. mediasubulussalam.com/2012/09/kafe-digrebek-79-botolmiras-dan-lima.html diakses pada tanggal 26 Juli 2015).

Kasus penangkapan tiga pasang remaja ini bila melihat kepada Pasal 2 Qanun Nomor 14 Tahun 2003 sudah dapat dikategorikan sebagai perbuatan khalwat yang mengarah kepada perbuatan zina. Seandainya kasus ini diselesaikan dengan peraturan qanun yang melarang setiap orang di Aceh berkhalwat, maka si pelakku bisa dijerat dengan Pasal 22 ayat 1-3 dengan ketentuan sebagai berikut:

Ayat (1) Setiap orang yang melanggar ketentuan sebagaimana dimaksud dalam pasal 4, diancam dengan 'uqubat $t a$ 'zi〉 berupa dicambuk paling tinggi 9 (sembilan) kali, paling rendah 3 (tiga) kali dan/atau denda paling banyak Rp. 10.000.000,- (sepuluh juta rupiah), paling sedikit $\operatorname{Rp} 2.500 .000,-$ (dua juta lima ratus ribu rupiah).

Ayat (2) Setiap orang yang melanggar ketentuan sebagaimana dimaksud dalam pasal 5 diancam dengan 'uqubat $t a^{\prime} z i>$ berupa kurungan paling lama 6 (enam) bulan, paling singkat 2 (dua) bulan dan/atau denda paling banyak Rp. 15.000.000,- (lima belas juta rupiah), paling sedikit Rp 5.000.000,- (lima juta rupiah).

Mengenai pemilik warung remang-remang di mana pada saat kejadian petugas WH hanya memberikan teguran di tempat supaya tidak lagi memberikan fasilitas kepada orang-orang untuk melakukan khalwat. Padahal dalam Qanun Nomor 14 pasal 6 telah secara tegas dilarang kepada setiap masyarakat, aparat pemerintah dan badan 
usaha untuk memberikan fasilitas khalwat dan apabila pasal ini dilanggar, kelompok masyarakat atau aparat pemerintah atau badan usaha dapat dikenakan sanksi berupa 'uquba»ta'zi»sebagaimana yang di atur dalam pasal 22 ayat (1) dan (2). Selain sanksi yang diatur dalam pasal 22, penjual atau pemilik usaha juga dikenakan hukuman tambahan berupa pencabutan atau pembatalan izin usaha yang telah diterima ('uqubatadministratif).

Dari ketiga contoh di atas dapat disimpukan bahwa Qanun No. 14 Tahun 2003 masih memiliki celah yang berakibat kepada ketidakefektivan qanun tersebut. Sebenarnya yang menjadi pertanyaan adalah ukuran khalwat yang bagaimanakah yang bisa dikategorikan dapat diselesaikan melalui mahkamah adat? Lalu bagaimana dengan khalwat yang sudah menjurus kepada perbuatan zina? Seperti yang terdapat dalam kasus nomor tiga di atas. Sebab apabila tidak jelas ukurannya, maka mahkamah adat akan menganggap seluruh kasus khalwat/mesum (meskipun sudah masuk berat/perzinaan) tetap akan diselesaikan melalui mahkamah adat. Dapat kita bayangkan, jika khalwat/mesum kategori berat/zina hanya dihukum dengan cara dinikahkan atau dikenakan denda adat, tentu hal tersebut sudah bertentangan dengan semangat syariat Islam yang telah diterapkan di Aceh.

Di sisi lain masyarakat dan pemangku adat seolah-olah merendahkan dan meremehkan Qanun No. 14 Tahun 2003 (qanun itu sendiri sebenarnya berdasarkan kepada Alquran) di mana dalam satu permasalahan lebih mengutamakan hukum adat ketimbang hukum syariat (ketentuan dari Allah), sebagaimana telah terjadi dalam masyarakat di satu daerah, kenyataannya lebih mementingkan dalam penyelesaian perdamaian ketika terdapat masalah untuk mencari islah, cukup hanya dengan tradisi mengtepung tawari (peusijuek) maka perdamaian sudah selesai, bukannya lebih mengutamakan hukum syariat hingga saat ini masih tetap dilaksanakan dalam masyarakat Aceh, sementara syariat seperti memberikan sanksi hukum yang telah dijelaskan dalam Alquran dan Hadis (Ridwan Hasan, 2009: 1). 
Hal seperti ini tampaknya sama dengan "explanatory memorandum" dari rekomendai dewan Eropa No. R (99) 19 tentang "Mediation in Penal Matters", dikemukakan model mediasi penal "community panels or courts". Model ini merupakan program untuk membelokkan kasus pidana dari penuntutan atau peradilan pada prosedur masyarakat yang lebih fleksibel dan informal dan sering melibatkan unsur mediasi atau negosiasi. Model "family and community group conferences" ini tidak hanya melibatkan korban dan pelaku tindak pidana, tetapi juga keluarga pelaku dan warga masyarakat lainnya, pejabat tertentu (seperti polisi dan hakim) dan para pendukung korban. Pelaku dan keluarganya diharapkan menghasilkan kesepakatan yang komprehensif (Barda Nawawi, 2010: 7).

Ketika penulis menanyakan hal mengenai batasan-batasan khalwat yang dapat dikategorikan penyelesaiannya melalui mahkamah adat dan mahkamah syar'iyah kepada wilayatul hisbah Kota Subulussalam, Bapak Kalidin selaku Kasi Penegakan qanun syariah menjelaskan bahwa ada beberapa kategori/kelompok yang mejadi pedoman WH Kota Subulussalam dalam penyelesaian kasus khalwat, diantaranya adalah:

1. Khalwat yang dikategorikan sebagai khalwat ringan, contohnya adalah seorang laki-laki dan perempuan (bukan muhrim) berduan di tempat yang sepi jauh dari keramian, menurutnya itu adalah khalwat yang dikategorikan kepada khalwat yang ringan, dimana penyelesaiannya tidak perlu melalui mahkamah syar'iyah, namun cukup diberikan bimbingan dan teguran di tempat bahwasanya perbuatan seperti itu melanggar syariat Islam dan dapat merusak moral;

2. Khalwat yang dikategorikan sebagai khalwat sedang, contohnya adalah seorang laki-laki dan perempuan (bukan muhrim) berduaan di tempat yang sepi dan jauh dari keramaian serta melakukan perbuatan seperti berciuman dan berpelukan. Apabila tertangkap tangan, maka kasusnya tidak perlu dilimpahkan ke mahkamah syar'iyah akan tetapi pelaku diamankan dan di bawa 
ke kantor wilayatul hisbah untuk dilakukan pembinaan dan nasehat serta memanggil orang tua/wali dari kedua orang yang tertangkap tangan tersebut begitu juga dengan geucik (kepala desa) masing-masing dari gampong yang tertangkap.

3. Khalwat yang dikategorikan sebagai khalwat berat, contohnya adalah seorang laki-laki dan perempuan yang tidak memiliki tali ikatan perkawinan, telah melakukan perbuatan yang bertentangan dengan syara' yakni berhubungan layaknya seperti suami istri (zina), maka apabila tertangkap, penyelesaian kasusnya akan diserahkan kepada penyidik polri (karena saat ini WH Kota Subulussalam belum memiliki penyidik sendiri/PPNS) guna dilakukan penyidikan dan diteruskan kepada jaksa guna untuk dilakukan penuntutan di mahkamah syar'iyah atau diserahkan kepada lembaga adat untuk diselesaikan secara adat yang berlaku di daerahnya.

Dari keterangan Kalidin di atas sebenarnya bukanlah suatu aturan yang baku untuk diikuti oleh semua anggota WH di Aceh, menurut penulis hal itu lebih kepada interpretasi dari penanganan kasus khalwat di Subulussalam, karena dalam Qanun 14 Tahun 2003 maupun dalam Qanun Nomor 6 Tahun 2014 tidak ada pasal yang mejelaskan mengenai kategori perbuatan khalwat dan bentuk hukuman dari kategori-kategori tersebut, pastinya setiap perbuatan khalwat adalah haram dan barang siapa melakukan perbuatan khalwat dapat di ancam dengan cambuk sebanyak 9 kali (14/2003) dan 10 kali (6/2014).

Sebenarnya permasalahan utama dalam hal penanganan kasus khalwat terletak kepada dualisme lembaga penyelesaian yakni mahkamah adat dan mahkamah syar'iyah, dengan demikian timbul suatu ketidakpastian dalam penanganan kasus tersebut khususnya bagi lembaga penegah hukum (WH, Polisi, Jaksa dan Mahkamah Syar'iyah). Bila kita amati dalam Qanun Aceh Nomor 9 Tahun 2008 tentang Pembinaan Kehidupan dan Adat Istiadat telah di atur secara tegas dalam bab tersendiri mengenai penyelesaian sengketa dan mekanismenya. Pasal 13 ayat (1) di tegaskan bahwa jenis 
sengketa/perselisihan adat dan adat istiadat meliputi 18 perkara dan khalwat (mesum) merupakan salah satu perkara yang menjadi kewenangan mahkamah adat di Aceh.

Pasal di atas secara tegas telah ditentukan 18 macam perkara yang dapat diselesaikan melalui peradilan adat, sebagaimana lazimnya dalam paradigma hukum adat, jenis-jenis perkara tidak dibedakan dalam kelompok bidang hukum publik, administratif, ataupun hukum privat. Bagi hukum adat, semua jenis perkara adalah bersifat publik atau communal.

Terkait kewenangan mahkamah adat dalam menyelesaiakan kasus khalwat (mesum) perlu dipikirkan ulang apakah pantas diselesaikan melalui mahkamah adat atau tidak? Kalau misalnya memang sudah patut diselesaikan oleh mahkamah adat, maka ukuran mesum yang bagaimana yang boleh? Sebab apabila tidak jelas ukurannya, maka mahkamah adat akan menganggap seluruh kasus mesum (meskipun sudah masuk berat/perzinaan) tetap akan diselesaikan melalui mahkamah adat. Dapat kita bayangkan seperti apa Aceh ke depan, jika mesum ketegori berat/zina hanya dihukum dengan cara dinikahkan atau dikenakan denda adat berupa besih lante (denda dengan membayar sejumlah uang sebagai isyarat membersihkan kampung) di wilayah Aceh Tengah dan sekitarnya, atau hanya dengan denda seekor kambing untuk wilayah Aceh daratan (Teuku Muttaqin Mansur, 2015)

Untuk lebih mempertegas mengenai penanganan terhadap pelanggaran khalwat, sudah seharusnya para pemangku kepentingan seperti Dinas Syariat Islam, Wilayatul Hisbah, Majelis Adat Aceh dan Majelis Permusyawaratan Ulama untuk duduk bersama dan merumuskan tentang ruang lingkup penanganan kasus khalwat. Dalam artian harus dipertegas bentuk pelanggaran apa saja yang menjadi kewenangan masing-masing (baik mahkamah syar'iyah maupun mahkamah adat) (Wildan Sastra, 2015). Sehingga ada kepastian bentuk hukuman bagi mereka yang melanggar ketentuan Qanun No. 14 Tahun 2003. 
Saat ini ada suatu asumsi yang beredar di tengah masyarakat Kota Subulussalam bahwa, mereka beranggapan apabila mereka melanggar qanun syariah hukuman yang diterima palingan hanya sekedar ditegur atau diperingati saja oleh wilayatul hisbah (Sapri TB, 2015) Itulah kesan yang ada di dalam pikiran masyarakat Kota Subulussalam saat ini, hal ini di karenakan selama ini wilayatul hisbah tidak membuat suatu gebrakan yang berarti dalam proses penegakan qanun syariat di kota ini, hal tersebut dapat dilihat dari data tingkat pelanggaran terhadap Qanun No. 14 tahun 2003 selama 6 tahun terakhir di atas.

Demi mengembalikan ruh syariat Islam yang kian memudar di Aceh dan khususnya di Kota Subulussalam, sudah saatnya kasus mesum (khalwat) yang selama ini diselesaikan melalui mahkamah adat agar dapat dikembalikan penyelesaiannya sesuai dengan Qanun No.14 Tahun 2003 tentang Khalwat (mesum) atau dengan qanun yang merubahnya (Qanun No. 6 Tahun 2014). Karena hal tersebut sesuai dengan prinsip-prinsip syariat Islam, dasar perundang-undangan dan lebih penting lagi ialah dasar pembentukan Aceh yang berlandaskan Islam yang selalu dibangga-banggakan selama ini. Jadi, sebaiknya, penyelesaian kasus khalwat (mesum) tetap melalui mahkamah syar'iyah tidak melalui mahkamah adat (peradilan adat).

\subsection{Penyelesaian Melalui Mahkamah Syar'iyah}

Pelaksanaan syariat Islam yang sangat spesifik di Provinsi Aceh adalah pelaksanaan hukuman cambuk bagi mereka yang terbukti melanggar qanun syariat Islam, seperti pelanggaran tentang judi, minuman keras, dan berduaan dengan pasangan lain jenis (khalwat). Semua itu telah diatur dalam Qanun No. 12 Tahun 2003, Qanun No. 13 Tahun 2003, Qanun No. 14 Tahun 2003, dan Qanun No. 7 Tahun 2004 (Dede Hendra Mr, 2012:141). Prosesi penjatuhan hukuman cambuk bagi mereka yang dinyatakan bersalah telah melanggar salah satu dari qanun jinayat harus memiliki kekuatan hukum tetap (inkracht). 
Pelaksanaan hukum cambuk terhadap terpidana khalwat di Kota Subulussalam dalam hal ini Aceh Singkil (Karena Kota Subulussalam baru dibentuk pada tahun 2007 melaui UU No. 8 Tahun 2007), menurut rekapitulasi data dari Mahkamah Syar'iyah Provinsi Aceh dalam kurun waktu 2005-2011 tidak ada ada satu kasuspun yang masuk apalagi diputus di Mahkamah Syar'iyah Singkil (Juaga Putri Sahadat Bancin, 2015: 46-47). Ketika penulis mengonfirmasi hal ini kepada Wilayatul Hisbah Kota Subulussalam, mereka menjelaskan bahwa hal itu dikarenakan penanganan kasus khalwat tidak hanya dapat diselesaikan melalui mahkamah syar'iyah tapi juga dapat diselesaikan melalui rapat kekeluargaan dan hukum adat (Kalidin, 2015).

Barulah pada tahun 2015 tepatnya pada bulan Mei Mahkamah Syar'iyah Singkil memutuskan dan menjatuhkan hukuman cambuk kepada dua orang (sepasang) khalwat (mesum) melalui putusan Jinayat Mahkamah Syar'iyah Singkil No. 03/JN/2015/MS-Skl dengan tersangka yang berinisial A (lk) dan M (pr) dicambuk sebanyak 9 kali cambuk dipotong masa tahanan (2 kali cambuk) menjadi 7 kali cambuk (http://subulussalamkota.go.id/v1.1/eksekusi-pelanggar-qanun142003-di-kota subulussalam, dikases pada tanggal 6 Juni 2015). Sebenarnya menurut Jujur Kurniawan selaku penyidik pembantu Polres Aceh Singkil, ada dua pasang kasus mesum yang mereka tangani pada waktu itu, hanya saja satu kasus tidak di limpahkan kepada Kejaksaan Negeri Singkil (dihentikan), karena yang bersangkutan telah menyelesaikan perkaranya melalui peradilan adat berupa pernikahan yang dibuktikan dengan kutipan aktan nikah No. 0073/010/IV/2015 tertanggal 9 April 2015, serta adanya surat permohonan dari kedua keluarga terpidana khalwat untuk menghentikan proses penyidikan tindak pidana khalwat kepada kedua pelaku karena telah diselesaikan melalui rapat keluarga dan adat berupa pernikahan (Jujur Kurniawan, 2015).

Terlepaas dari perdebatan di atas, penulis menilai bahwa pelaksanaan hukum cambuk terhadap kedua pelaku khalwat tersebut merupakan suatu langkah maju dalam pelaksanaan syariat Islam di 
Kota Subulussalam. Pencambukan ini setidaknya dapat memberikan pesan yang tersirat kepada masyarakat Kota Subulussalam akan perlunya dukungan pelaksanaan syariat dengan tidak melanggar ketentuan-ketentuan yang berlaku di Aceh. Ketua Permusyawaratan Ulama Kota Subulussalam, Ust. H. Qaharuddin Kombih menjelaskan bahwa sudah seharusnya menjadi kewajiban bagi setiap muslim untuk menaati ketentuan-ketentuan syariat Islam terlepas dari diatur dalam qanun ataupun tidak, menurutnya masyarakat harus takut akan azab Allah apabila kita tidak mengikuti ketentuan-ketentuan yang telah digariskan (Qaharuddin Kombih, 2015).

Pelaksanaan hukum cambuk di Kota Subulussalam dilaksanakan pada hari Senin 11 Mei 2015 oleh Dinas Syariat Islam Kota Subulussalam di lapangan Beringin Kota Subulussalam terhadap sepasang sejoli yang tertangkap melakukan perbuatan mesum. Mengenai kronologis penangkapan pasangan mesum ini bermula dari laporan masyarakat yang menjelaskan bahwa salah satu cafe di kawasan Lae Kombih sering dijadikan sebagai tempat mesum oleh kalangan remaja maupun pasangan selingkuh. Satpol PP dan WH Kota Subulussalam pada hari Sabtu 4 April 2015 melakukan razia rutin bulanan yang menjadikan tempat yang dilaporkan masyarakat tersebut menjadi salah satu target operasi. Kedua pasangan mesum ini didapati aparat sedang berdua-duaan di tempat sepi dengan pakaian setengah tersingkap di sebuah kafe di bantaran Lae (sungai) Kombih Gampong Penanggalan sekitar pukul 21.00 WIB. Kedua tersangka kemudian diamankan dan dibawa ke kantor $\mathrm{WH}$, setelah dilakukan pengintrogasian ternyata pelaku laki-laki adalah seorang yang sudah menikah (sudah beristri dan mempunyai anak) dengan inisial A (32) warga Gampong Singgersing Kecamatan Sultan Daulat Kota Subulussalam, sedangkan pasangannya adalah seorang janda muda yang tidak memiliki anak dengan berinisial $M$ (25) yang merupakan warga Gampong Kuta Cepu Kecamatan Simpang Kiri Kota Subulussalam.

Kedua pelaku kemudian diserahkan kepada penyidik polri untuk dilakukan penyidikan, setelah dilakukan penyidikan kedua 
tersangka dinyatakan kuat telah melanggar ketentuan Qanun No. 14 Tahun 2003. Kedua pasangan ini kemudian dijerat dengan pasal 22 ayat (1) Qanun No. 14 Tahun 2003 tentang Khalwat dengan ancaman 'uquba ta'zi» berupa dicambuk paling tinggi 9 (sembilan) kali, paling rendah 3 (tiga) kali dan/atau denda paling banyak Rp. 10.000.000,(sepuluh juta rupiah), paling sedikit Rp 2.500.000,- (dua juta lima ratus ribu rupiah). Pasangan mesum ini kemudian diserahkan kepada Kejaksaan Negeri Singkil.

Hasil putusan Mahkamah Syar'iyah Singkil memutuskan kedua pasangan mesum ini masing-masing dikenakan hukuman 9 (sembilan) kali cambukan dipotong masa tahanan 1 bulan 6 hari (pemotongan 2 kali cambukan), sehingga ketika eksekusi dilakukan masing-masing terhukum hanya menjalani 7 kali cambukan (Polres Singkil, Pelaksanaan Ukubat Cambuk Pelaku Khalwat/Mesum, diakses pada tanggal 27 Juli 2015). Menurut Harri C. Kesuma selaku Jaksa Penuntut Umum Kejaksaan Negeri Singkil, sebelum kedua tersangka dieksekusi cambuk, keduanya menjadi tahanan Kejaksaan Negeri Singkil dan tersangka telah menjalani hukuman penahanan selama 36 hari sebelum eksekusi cambuk tersebut dijalani. Menurutnya setelah penjatuhan cambuk ini, kedua tersangka tidak ditahan lagi dan sudah diperbolehkan untuk pulang ke rumahnya masing-masing (Harri C. Keusume, 2015).

Pelaksanaan hukuman terhadap keduanya berjalan lancar walaupun tercambuk perempuan $M$ (25) sempat menangis setelah dicambuk karena merasa malu atas peristiwa pencambukan tersebut. Sedangkan tercambuk laki-laki A (32) terkesan tidak memiliki beban pada saat menerima cambukan dari sang algojo yang ditunjuk, sama seperti 10 orang yang dicambuk akibat maisir yang sudah dijelaskan pada bab sebelumnya, terhukum masih bisa senyum dan melambaikan tangan ke arah warga yang menyaksikan proses pencambukan tersebut (seolah bak suatu kebanggaan dapat dicambuk). Sepertinya hukuman cambuk ini bukanlah suatu momok yang menakutkan lagi bagi warga Subulussalam khususnya terpidana laki-laki, hal ini dapat dilihat dari dua kasus pencabukan di kota ini, 
apakah karena hukumannya yang diterima terlalu ringan bagi mereka atau memang budaya malu itu sudah hilang sama sekali.

Kepala Dinas Syariat Islam Kota Subulussalam M.Ya'qub KS mengatakan, pencambukan ini dilakukan tujuannya untuk memberikan efek jera kepada warga yang lainnya agar tidak melakukan perbuatan seperti ini yang melanggar aturan hukum agama, negara dan tatanan budaya kita, tidak lebih dari itu. Dalam upaya penegakan syariat Islam di Aceh dan Kota Subulussalam secara khusus, daerah berkewajiban untuk mengimplementasikan penegakannya sesuai Qanun Aceh. Melalui eksekusi ini diharapkan kepada pelanggar syariat Islam untuk bertaubat dan berdaya upaya untuk menjauhi perbuatan maksiat tersebut, "Kita bukan mau mempertontonkan mereka, tapi memberikan tindakan agar menjadi contoh bagi yang lainnya dan semoga ada hikmahnya, pelaksanaan hukum cambuk itu bukanlah suatu kebanggaan". (M Ya'qub KS, 2015).

Sementara itu Kejaksaan Negeri Singkil, yang diwakili oleh Bapak Irfan Hasyri dalam sambutannya menyatakan eksekusi cambuk bukan bermaksud untuk menyakiti atau menyiksa warga yang menjadi terpidana kasus terkait. Namun, hukuman cambuk tersebut guna memberi efek jera bagi warga yang melanggar qanun syariat Islam. Makanya, proses cambuk tersebut digelar di depan umum dengan maksud dapat menjadi contoh bagi masyarakat lain sehingga tidak melakukan perbuatan serupa di kemudian hari.

Ketua Majelis Permusyawaratan Ulama (MPU) Kota Subulussalam H. Qaharudin Kombih berpesan kepada semua pihak untuk mengingat adzab Allah bagi yang melanggar syariat Allah. Kepada semua penegak hukum dan semua stakeholder untuk menjalankan amanah Allah, siapapun yang melanggar syariat Islam agar dihukum jangan pandang bulu, mari laksanakan syariat Islam dengan baik dan penuh rasa tanggungjawab kepada diri dan Allah SWT (H. Qaharuddin Kombih, 2015). 


\subsection{Faktor Mempengaruhi dalam Penegakan Qanun Khalwat di Kota Subulussalam (Faktor Hukum dan Non-Hukum)}

Banyak faktor yang mempengaruhi dalam efektivitas penegakan Qanun Khalwat di Kota Subulussalam. Menurut Soerjono Soekanto masalah pokok dalam penegakan hukum adalah terletak pada hukumnya sendiri (peraturan perundang-undangan yang berlaku), penegak hukumnya yakni pihak-pihak yang mengawal penerapan hukum, sarana atau fasilitas yang mendukung penerapan hukum, masyarakat di mana hukum tersebut diberlakukan dan budaya hukum dalam masyarakatnya (Soerjono Soekanto, 2008: 8). Kelima faktor tesebut saling memiliki kaitan yang erat dikarenakan esensi dari penegakan hukum. Kelima faktor tersebut merupakan tolak ukur daripada efektivitas penerapan hukum.

\subsubsection{Faktor Undang-undang (Qanun)}

Bila kita mengkaji Qanun No. 14 Tahun 2003 tentang Khalwat, maka kita akan menemui suatu kepastian bentuk 'uqubatbagi mereka yang melanggar ketentuan-ketentuan khalwat di Aceh. Qanun ini tegas mengatakan bahwa perbuatan khalwat adalah haram, dan barang siapa yang melanggar ketentuan tersebut dapat di kenakan 'uqubat ta'zi> berupa cambuk paling banyak 9 (sembilan) kali cambukan. Begitu juga dengan Qanun No. 6 Tahun 2014 tentang Hukum Jinayat yang merupakan pembaharu terhadap Qanun No. 14 Tahun 2003, dikatakan bahwa hukum berkhalwat adalah haram dan setiap orang yang melanggar ketentuan tersebut diancam dengan 'uquba ta'zið berupa cambuk sebanyak 10 (sepuluh kali) cambukan.

Sebenarnya kelemahan utama yang terdapat dalam Qanun No. 14 tahun 2003 adalah tidak adanya kewenangan yang diberikan kepada wilayatul hisbah untuk melakukan penahanan, WH tidak berwenang menahan dan memeriksa, sehingga penahanan yang dilakukan WH merupakan tindakan melanggar ketentuan hukum dan melampaui batas kewenangan. Kewenangan yang dimiliki WH hanya sebatas melakukan pengawasan terhadap penegakan syariat Islam 
sekaligus melakukan pembinaan terhadap para pelanggar syariat Islam yang sedang berlaku di Aceh dan tidak ada kewenangan WH melakukan penahanan terhadap para pelanggar pelaku Syariah di Aceh bila berdasarkan kepada Qanun No. 14 Tahun 2003. (Sarkani, 2015). Apabila WH menangkap pelaku pelanggaran khalwat akan dilimpahkan perkaranya ke pihak penyidik di kepolisian, dan pihak kepolisianlah yang berwenang melakukan penahanan terhadap mereka (Keputusan Gubernur Aceh, No 1, 2014).

Kendala selanjutnya adalah adanya benturan antara qanun dalam penanganan kasus khalwat, selain di atur dalam Qanun No. 14 Tahun 2003 dan ditegaskan kemabali dalam Qanun No. 6 Tahun 2014 juga di atur dan menjadi salah satu kewenangan dari peradilan adat di Aceh, hal ini di jelaskan dalam Qanun No. 9 Tahun 2008 Tentang Pembinaan Kehidupan Adat dan Adat Istiadat. Dalam Pasal 13 ayat (1) dijelaskan bahwa khalwat merupakan salah satu dari 18 kewenangan yang di berikan kepada mahkamah adat di Aceh. Hal inilah yang menjadi celah permasalahan baru dalam penerapan Qanun Khalwat di Aceh dan khususnya Kota Subulussalam.

Dengan adanya Qanun No. 9 Tahun 2008, setiap pelanggaran khalwat yang terjadi Aceh harus diselesaikan melalui peradilan adat terlebih dahulu, Apabila bisa diselesaikan dalam peradilan adat, maka pihak berwenang dalam hal ini WH tidak berwenang lagi untuk menindaklanjuti kasus tersebut (Kalidin, 2015). Mengenai mekanisme penyelesaian kasus khalwat di lembaga adat akan disesuaikan dengan kebiasaan adat di wilayah masyarakat setempat, bararti hukum adat di Aceh tidak memiliki standar tertentu dalam mekanisme penyelesaiannya, hal ini dikarenakan masyarakat Aceh yang majemuk dan terdiri dari beberapa suku yang berbeda (Putri Sahadat Bancin, 2015).

Adanya dualisme lembaga dalam penyelesaian kasus khalwat di Aceh merupakan kendala tersendiri bagi WH dalam menegakkan Qanun Khalwat. Satu penelitian terkait dengan khalwat/mesum di kota Lhokseumawe yang dilakukan Abdullah, seorang dosen Sekolah Tinggi Agama Islam Negeri (STAIN) Lhokseumawe menyebutkan, 
berkurangnya penyelesaian kasus khalwat/mesum melalui WH dan mahkamah syar'iyah karena penyelesaian kasus khalwat/mesum telah bergeser. Kasus khalwat/mesum saat ini lebih mengutamakan penyelesaian secara adat ketimbang kepada jalur WH dan mahkamah syar'iyah.

Hasil penelitian itu telah dipaparkan dalam Aceh Development International Conference (ADIC) yang berlangsung pada 27 Maret 2013 di Kuala Lumpur. Apa yang disimpulkan Abdullah, barangkali ada benarnya, Sebab sejak Majelis Adat Aceh (MAA) melakukan sosialisasi penyelesaian kasus masyarakat melalui adat dalam beberapa tahun terakhir, maka kasus-kasus yang masuk dalam kategori 18 kasus adat sesuai dengan amanah Qanun No. 9 Tahun 2008, bisa diselesaikan melalui mahkamah adat di Gampong ataupun mukim (Teuku Muttaqin Mansur, 2013).

Untuk mengatasi hal tersebut, sudah saatnya para pemangku kepentingan untuk duduk bersama dan merumuskan mekanisme penyelesaian kasus khalwat di Aceh, khususnya di Subulussalam. Hal ini penting dilakukan guna untuk mempertegas mengenai ketentuanketentuan khalwat seperti apa yang menjadi wilayah kewenangan masing-masing lembaga. Karena selama ini penanganan kasus khalwat menurun penyelesaiannya di tingkat mahkamah syar'iyah, disamping itu ada yang beranggapan bahwa hukuman yang diberikan lembaga adat terhadap pelaku khalwat di nilai kurang adil, karena bentuk hukumannya kurang begitu tegas dan tidak menimbulkan efek jera bagi para pelakunya. Di Kota Subulussalam sendiri penyelesaian kasus khalwat ditempuh dengan jalur kekeluargaan, sebagaimana telah dijelaskan di atas, dimana kedua keluarga yang tersangka khalwat/mesum duduk bersama untuk mencari solusi terhadap penyelesaian kasus tersebut dengan hukuman yang sering di capai adalah pemberian nasehat, perdamaian, pernyataan maaf, ganti rugi/denda dan dinikahkan (H.M Layari Kombih, 2015). 


\subsubsection{Faktor Penegak Hukum}

Sejak hukum itu mengandung perintah dan pemaksaan, maka sejak itu pula hukum membutuhkan bantuan untuk mewujudkan perintah tersebut. Hukum menjadi tidak ada artinya, bila perintahnya tidak dapat dilaksanakan, karena itu diperlukan usaha dan tindakan manusia agar perintah dan paksaan yang secara potensial ada di dalam peraturan itu menjadi nyata dalam praktik hukum. Donald Black, sebagaimana dikutip Sadjipto Rahardjo mengatakan bahwa dimensi keterlibatan manusia dalam penegakan hukum tersebut dinamakan dengan mobilisasi hukum. Dalam mobilisasi hukum inilah manusia turut campur sehingga hukum tidak hanya mengancam dan berjanji di atas kertas (Danial, 2003"Vol. 45, No. I, 2011, 1004)

Wilayatul Hisbah dan Sat Pol PP Kota Subulussalam saat ini memiliki 139 orang anggota dan keseluruhan dari anggota tersebut berpusat di Kantor Pol PP dan WH Kota Subulussalam di Subulussalam. Adapun status dari 139 orang anggota tersebut, baru 15 orang yang diangkat menjadi pegawai negeri sipil (PNS) dan sisanya masih berstatus sebagai pegawai honorer (Abdul Malik, 2015). Selain itu WH Kota Subulussalam juga belum mempunyai Penyidik Pegawai Negeri Sipil (PPNS), padahal keberadaan PPNS ini sangat di butuhkan guna untuk proses penyelidikan dan penyidikan yang dilakukan WH terhadap pelaku pelanggaran qanun jinayat di Kota Subulussalam.

Ketersediaan sumber daya manusia yang memadai sangat mempengaruhi efektivitas suatu hukum. Berdasarkan keterangan di atas, bahwa saat ini wilayatul hisbah dan Pol PP Kota Subulussalam memiliki 139 anggota di mana 15 belas di antaranya adalah PNS, sisanya pengawai honorer yang kebanyakan memiliki latar belakang pendidikan Sekolah Menengah Atas (SMA) (Bambang Aprianto, 2015). Pendidikan para penegak hukum ini (WH) sangat vital dalam penegakan hukum syariah di Aceh, karena hukum yang akan ditegakkan nantinya bukanlah hukum yang berdasarkan kepada UUD sebagai landasan utama pembuatan hukumnya, akan tetapi 
Alquran dan Hadis. Maka untuk itu setiap anggota WH di tuntut untuk memilik kecakapan dalam bidang hukum Islam (fikilh). Inilah yang menjadi permasalahan selama ini, di mana masyarakat menilai, para penegak hukum syariah di Kota Subulussalam belum layak untuk dijadikan sebagai penegak qanun jinayat. Hal ini dikarenakan sikap dan perilaku keseharian anggota WH yang belum mencerminkan nilai-nilai keislaman dalam kehidupan masyarakat sehari-hari di luar masa tugasnya (Arifin Sarbaini, 2015). Memang dalam perekrutan anggota WH selama ini belum ada standar yang khusus mengenai latar belakang pendidikan bagi anggota $\mathrm{WH}$. Menurut Wildan Sastra selaku pemerhati syariat Islam dan gender kota Subulussalam, sudah seharusnya WH Kota Subulussalam membuat standar khusus bagi para WH, sehingga dalam penegakan qanun-qanun syariat anggota WH bisa mengetahui dengan baik dan benar, begitu juga dalam kehidupan bermasyarakat sehari-hari, anggota WH diharapkan bisa memberikan contoh yang nyata kepada masyarakat akan perlunya menegakkan syariat Islam di Kota Subulussalam.

\subsubsection{Faktor Fasilitas Penunjang Penegakan Hukum}

Keberadaan Kantor WH seharusnya tidak hanya berada di satu titik tertentu, tapi harus ada di setiap kecamatan-kecamatan di Kota Subulusssalam. Hal ini dilakukan supaya keberadaan $\mathrm{WH}$ dapat dirasakan langsung oleh masyarakat bukan hanya sebagai simbol dari pelengkap lembaga-lembaga daerah di Aceh. Dalam Keputusan Gubernur No. 1 Tahun 2004 Tentang Pembentukan Organisasi dan Tata Kerja Wilayatul Hisbah disebutkan bahwa susunan organisasi Wilayatul Hisbah, terdiri atas; Wilayatul Hisbah Tingkat Provinsi; Wilayatul Hisbah Tingkat Kabupaten/Kota; Wilayatul Hisbah Tingkat Kecamatan, dan Wilayatul Hisbah Tingkat Kemukiman. (Hirwan Jack, 2015). Berarti pembentukan kantor WH di setiap kecamatan sangat mungkin untuk dibentuk karena telah mempunyai landasan hukum yang kuat. 


\subsubsection{Faktor Kesadaran Hukum Masyarakat yang Masih Rendah}

Kesadaran hukum masyarakat secara umum masih rendah. Keterlibatan masyarakat dalam mengawal Qanun Khalwat sangat mempengaruhi efektivitas pemberlakuan qanun tersebut. Dengan segala keterbatasan yang dimiliki oleh WH Kota Subulussalam, keterlibatan aktif masyarakat sangat dibutuhkan, karena bagaimanapun, perbuatan pelanggaran qanun khalwat dilakukan dan terjadi di tengah-tengah kalangan masyarakat Kota Subulussalam. Mengingat pentingnya peran dan kesadaran hukum masyarakat ini, Qanun Nomor 14 Tahun 2003 jauh-jauh hari telah memberikan ruang berupa peran aktif masyarakat dalam mengawal pemberlakuan qanun ini, seperti yang dijelaskan dalam BAB IV Pasal 8-12.

Kesadaran dan pengetahuan tentang qanun inilah yang dirasa masih kurang di tengah-tengah masyarakat. Di beberapa tempat, seperti Sultan Daulad, Runding dan Penanggalan, ketika penulis berdiskusi dengan masyarakat dan pemuda setempat mengatakan, tindak pelanggaran terhadap qanun jinayat, khususnya Qanun No. 14 Tahun 2003 sebenarnya sangat sering terjadi di daerah mereka masing-masing, masyarakat juga sudah merasa bosan untuk selalu mengingatkan bahwa perbuatan mereka bertentangan dengan qanun jinayat di Aceh. Pada akhirnya masyarakatpun cuek dan berharap petugas WH melakukan patroli ke wilayah mereka.

Kesadaran hukum masyarakat tidak dapat dipisahkan dari intensitas disseminasi dan penyuluhan yang dilakukan para penyelenggara pemerintah daerah (Aceh) kepada masyarakat. Setiap penyelenggara negara berkewajiban memberikan penyuluhan hukum sebagai bagian dari proses edukasi dan pembudayaan hukum. Penyuluhan hukum merupakan tanggung jawab setiap penyelenggara negara. Kesadaran hukum masyarakat ini sebenarnya bisa dibangun melalui bentuk/kegiatan sosialisasi tentang qanun-qanun jinayat khususnya Qanun No. 14 Tahun 2003. Dibutuhkan kesadaran yang tinggi dari masyarakat Kota Subulussalam untuk melaksanakan Syariat Islam, di samping itu, juga harus adanya political will 
pemerintah dan peran serta stakeholders dan tentunya dilakukan secara bertahap atau gradual.

\section{Penutup}

Larangan khalwat merupakan pencegahan dini terhadap perbuatan zina, karena perbuatan zina pada dasarnya di mulai dari hal-hal yang mengarah kepadanya. Dengan adanya formalisasi hukum jinaya $\diamond$ di Aceh dan penjatuhan 'uquba»terhadap pelaku pelanggaran tindak pidana khalwat, diharapkan dapat menjadi stimulus bagi penyadaran masyarakat dari berbagai latar belakang agama, ras, dan budaya tentang adanya pelaksanaan hukum jinayat di Aceh dan khususnya Kota Subulussalam. Qanun Jinayał No. 14 tahun 2003, qanun tersebut kemudaian disempurnakan dengan di sahkannya Qanun No. 6 Tahun 2014 Tentang Hukum Jinayat.

\section{Daftar Pustaka}

Abidin, Nurdin. "Revitalisasi Kearifan Lokal di Aceh: Peran Budaya Dalam Menyelesaikan Konflik Masyarakat", dalam Anlisis, Vol. XIII No. 1, Juni 2013.

Ali, Jainuddin. Sosiologi Hukum. Jakarta: Sinar Grafika, 2007.

Arief, Barda Nawawi. Mediasi Penal, Penyelesaian Perkara diluar Pengadilan. Semarang: Pustaka Magister, 2010.

Ablisar, Madiasa. "Relevansi Hukuman Cambuk Sebagai Salah Satu Bentuk Pemidanaan Dalam Pembaharuan Hukum Pidana", dalam Jurnal Dinamika Hukum Vol. 14, No. 2, Mei 2014.

Analiansyah. "Qanun Hukum Acara Jinayat Dalam Pelaksanaan Syari'at Islam Studi Terhadap Draf Qanun Hukum Acara Jinayat Di Aceh", Legitimasi, Vol.1 No. 1, Juli-Desember 2011.

Aziz, Samsudin. "Kanunisasi Fikih Jinayat Kontemporer Studi Materi

Muatan Qānūn Jināyat Aceh dan Brunei Darussalam", dalam Jurnal Pemikiran Hukum Islam (al-Ahkam), Volume 24, Nomor 2, Oktober 2014. 
Danial. "Efektifitas 'Uqūbat Dalam Qanun No. 14/ 2003 dan DQHRTentang Khalwat dan Ikhtilath," dalam Jurnal AsySyir'ah, Vol. 45, No. I, 2011.

Hasan, Ridwan. "Hukum Adat Vs Teologi Dan Syari'at Islam Dalam Wilayatul Hisbah Di Nanggroe Aceh Darussalam (NAD)", dalam The 9th Annual Conference On Islamic Studies (ACIS), Surakarta: 2009.

Hendra Mr, Dede. "Eksistensi Penerapan Pidana Cambuk Terhadap Pelanggar Qanun Syariat Islam Di Provinsi Aceh." Tesis, Fakultas Hukum UI, 2012.

Jack, Hirwan. "Efektivitas Wilayatul Hisbah Dalam Pencegahan Aliran Sesat Di Aceh", http://bkpp.acehprov .go.id/simpegbrr/Art ikel/Artikel05-02-2015/Wilayatul H i s bah_Aceh.pdf.

Keputusan Gubernur Aceh No. 01 Tahun 2004 tentang Kewenangan Pembentukan Organisasi Wilayatul Hisbah.

Komnas Perempuan, Analisi Terhadap Qanun Nangroe Aceh Darussalam.http://www.academia.edu /8145409/ Analisisterhadap-qanun-nangroe-aceh-darussa lam. https:// drive.google. $\mathrm{com} /$ file/d /0B5UQVcJ8Df8WenBNSWNfZUVMcTQ/view? pli=1.

Mansur, Teuku Muttaqin. Penyelesaian Kasus Mesum Melalui Mahkamah Adat atau Mahkamah Syar'iyah?, http://aceh.tribunnews.com/2013/09/04/ penyelesaian-kasusmesum-melalui-ma-atau-ms?page $=3$.

Media Subulussalam, Kafe Digrebek, 79 Botol Miras dan Lima Wanita Diamankanhttp://www.

mediasubulussalam.com/2012/09/kafe-digrebek-79-botolmiras-dan-lima.html.

Melayu, Husnul Arifin. "Hukum Cambuk dan Pengaruhnya Terhadap Kasus Khalwat di Aceh," Jurnal Jurnal Ar-Raniry, Media Kajian Keislaman Edisi I, No. 87, 2011.

Munawaroh, Hifdhotul. "Mediasi Adat Aceh Dalam Penyelesaian sengketa Perspektif Hukum Positif dan Hukum Islam." Tesis, Jakarta: UIN Syarif Hidayatullah, 2013. 
Polres Singkil, Pelaksanaan Ukubat Cambuk Pelaku Khalwat/Mesum, http:// poldaaceh.web.id/pelaksanaan-ukubat-cambukpelaku-khalwatmesum.html.

Prayitno, Kuat Puji. “Restorative Justice Untuk Peradilan Di Indonesia (Perspektif Yuridis Filosofis dalam Penegakan Hukum In Concreto)," dalam Jurnal Dinamika Hukum, Vol. 12, No. 3 September 2012.

Soekanto, Soerjono. Faktor-Faktor yang Mempengaruhi Penegakan Hukum. Jakarta: PT. Raja Grafindo Persada, 2008.

Yani, Muhammad. "Pelaksanaan Hukum Jinayat di Aceh Perspektif Fik\}ih dan HAM: Studi Qanun Nomor 12, 13 dan 14 Tahun 2003," Tesis, Jakarta: UIN Syarif Hidayatulah, 2011.

Wawancara dengan Abdul Malik, selaku Kepala Satpol PP dan WH Kota Subulussalam, 23 April 2015.

Wawancara dengan Arifin Sarbaini, selaku Ketua FPI Kota Subulussalam, 16 Agustus 2015.

Wawancara dengan Bambang Aprianto, Selaku Subag TU Pol PP dan WH Kota Subulussalam, 29 April 2015.

Wawancara dengan Bapak Kalidin, Kasie Penegak Kebijakan Daearah

Dan Syariat Islam Kota Subulussalam. Kantor Satuan Polisis

Pamong Praja dan Wilayatul Hisbah Kota Subulussalam, pada tanggal 23 April 2015.

Wawancara dengan Bpk. M Ya'qub KS, selaku Kepala Dinas Syariat Islam Kota Subulussalam pada tanggal 22 April 2015 bertempat di Kantor DSI Kota Subulussalam.

Wawancara dengan GM (nama disamarkan) Warga Sultan Daulad. AK (nama disamarkan) Warga Subulussalam Barat. M (nama disamarkan) Warga Rundeng. 10 Juni 2015.

Wawancara dengan H.M Layari Kombih, selaku Ketua Majelis Adat Aceh (MAA) Kota Subulussalam, bertempat dikantor MAA Kota Subulussalam pada tanggal 27 April 2015.

Wawancara dengan Kalidin, selaku Kasi Penegakan Syariat Islam Kota Subulussalam, 23 April 2015.

Wawancara dengan Sapri TB, Pemuda Sultan Daulat Kota Subulussalam, 20 Mei 2015. 
Wawancara dengan Sarkani, Kasi Ketentraman dan Ketertiban Pol PP dan WH Kota Subulussalam, 23 April 2015.

Wawancara dengan Ust. H. Qaharuddin Kombih, selaku Ketua MPU Kota Subulussalam, pada tangga 20 April 2015 di Pondok Pesantren Hidayatullah Kota Subulussalam.

Wawancara dengan Wildan Sastra, Pengamat Syariah dan Gender Kota Subulussalam, 12 Agustus 2015. 